\title{
ARBITRASE SEBAGAI ALTERNATIF PENYELESAIAN SENGKETA EKONOMI SYARIAH MENURUT UNDANG-UNDANG NOMOR 30 TAHUN 1999
}

\author{
Muhibuthabary \\ Fakultas Syari'ah dan Hukum UIN Ar-Raniry Aceh \\ E-Mail:muhib_nett@yahoo.com
}

\begin{abstract}
This paper describes the arbitration as an alternative dispute resolution in Shariah economy. Dispute resolution in general civil religion has resolved through litigation in the religious courts that refer to Article 49 of Law Number 7 of 1989 Jo. Law Number 3 of 2006 Jo. Law Number 50 of 2009 on the Religious Courts. However, there are some interesting cases, one of which is the Islamic economic disputes could be resolved through non-litigation or arbitration process, which refers to the Law No. 30 Year 1999. Now, the Shari'ah economic dispute resolution becomes the object of this study which interesting to study both theoretically and practically, not only because the case is to be part of the absolute authority of religious courts, but also becomes a new knowledge in the field of Islamic Jurisprudence.
\end{abstract}

\begin{abstract}
Abstrak
Tulisan ini akan menjelaskan tentang arbitrase sebagai salah satu alternatif dalam penyelesaian sengketa ekonomi syariah. Penyelesaian perkara perdata agama pada umumnya banyak diselesaikan melalui proses litigasi di Pengadilan Agama mengacu kepada Pasal 49 Undang-Undang Nomor 7 Tahun 1989 Jo. Undang-Undang Nomor 3 Tahun 2006 Jo. Undang-Undang Nomor 50 Tahun 2009 Tentang Peradilan Agama. Namun ada beberapa kasus menarik salah satunya ialah mengenai sengketa ekonomi syariah yang dapat diselesaikan melalui proses non litigasi atau identik dengan arbitrase, yang mengacu kepada Undang-Undang Nomor 30 Tahun 1999. Penyelesaian sengketa ekonomi syariah kini menjadi obyek kajian yang menarik untuk dikaji baik dari secara teoritis maupun praktis, bukan hanya karena perkara tersebut menjadi bagian dari kewenangan absolut Pengadilan Agama, tetapi juga menjadi pengetahuan baru di bidang Ilmu Hukum Islam.
\end{abstract}

Kata Kunci:

Arbitrase, Sengketa ekonomi syariah, Litigasi, Non Litigasi, Pengadilan Agama

\section{A. Pendahuluan}

Dalam setiap perjanjian selalu ada kemungkinan terjadinya sengketa yang melibatkan para pihak. Sengketa tersebut boleh jadi muncul akibat salah satu pihak tidak memenuhi kewajibannya kepada pihak lain danlatau dapat disebabkan salah satu pihak melakukan pengingkaran terhadap kesepakatan yang telah dibuat. Sebagai contoh, dalam perjanjian perdata, klausula arbitase banyak digunakan sebagai pilihan penyelesaian sengketa. Pendapat hukum yang diberikan lembaga arbitrase bersifat mengikat (binding) oleh karena pendapat yang diberikan terse- but akan menjadi bagian yang tidak terpisahkan dari perjanjian pokok yang dimintakan pendapatnya pada lembaga arbitrase tersebut.

Selain itu, setiap pendapat yang berlawanan terhadap pendapat hukum yang diberikan itu berarti pelanggaran terhadap perjanjian (breach of contract - wanprestasi). Oleh karena itu tidak dapat dilakukan perlawanan dalam bentuk upaya hukum apapun. Putusan Arbitrase tersebut bersifat mandiri, final dan mengikat (in kracht), sehingga Ketua Pengadilan tidak diperkenankan untuk memeriksa alasan atau pertimbangan dari 
putusan arbitrase nasional tersebut. Artinya, putusan lembaga arbitrase dianggap sah apabila ia dianggap telah memenuhi rasa keadilan bagi para pihak.

Berkenaan dengan hal tersebut, tulisan ini akan menjelaskan beberapa aspek yang terkait dengan penyelesaian sengketa melalui lembaga arbitrase dalam kasus perkara perdata. Fokus dari tulisan ini akan menyajikan pengertian dan landasan hukum arbitrase, obyek dan jenis arbitrase, syarat dan prosedur arbitrase, manfaat arbitrase dalam proses penegakan hukum, dan contoh analisis kasus penerapan arbitrase dalam proses penyelesaian sengketa hukum perdata.

\section{B. Pengertian Arbitrase}

Secara bahasa, kata arbitrase adalah berasal dari kata arbitrare (Latin) yang berarti kekuasaan untuk menyelesaikan sesuatu menurut kebijaksanaan. Arbitrase berasal dari bahasa asing yaitu arbitrare. Arbitrase juga dikenal dengan sebutan atau istilah lain yang mempunyai arti sama, seperti: perwasitan atau arbitrage (Belanda), arbitration (Inggris), arbitrage atau schiedsruch (Jerman), arbitrage (Prancis) yang kesemuanya memiliki arti hampir sama, yaitu kekuasaan untuk menyelesaikan sesuatu menurut kebijaksanaan. ${ }^{1}$

Sedangkan secara istilah, arbitrase adalah cara penyelesaian sengketa diluar peradilan umum yang didasarkan pada kontrak arbitrase secara tertulis oleh para pihak yang bersengketa, di mana pihak penyelesaian sengketa tersebut dipilih oleh para pihak yang bersangkutan yang terdiri dari orangorang yang tidak berkepentingan dengan perkara yang bersangkutan, orang-orang mana akan memeriksa dan memberi putusan terhadap sengketa tersebut. ${ }^{2}$

Keberadaan arbitrase sebagai salah satu alternatif penyelesaian sengketa sebenarnya sudah lama dikenal meskipun jarang dipergunakan. Istilah arbitrase pertama kali diperke-

\footnotetext{
1'http://www.wikipedia.org/arbitrase, diakses tanggal 10 September 2013.

${ }^{2}$ Jacqueline M. Nolan-Haley, Alternative Dispute Resolution in a Nutshell (St. Paul: West Publishing Co. 1992), hlm. 4.
}

nalkan di Indonesia bersamaan dengan dipakainya Reglement op deRechtsvordering (RV) dan Het Herziene Indonesisch Reglement (HIR) ataupun Rechtsreglement Bitengewesten (RBg), karena semula Arbitrase ini diatur dalam pasal 615 s/d 651 Reglement of De Rechtvordering. Ketentuan-ketentuan tersebut sekarang inisudah tidak laku lagi dengan diundangkannya Undang-Undang Nomor 30 Tahun 1999.

Baru kemudian setelah ditetapkannya Undang-Undang Nomor 14 Tahun 1970 Tentang Pokok-Pokok Kekuasaan Kehakiman, keberadaan arbitrase dapat dilihat dalam penjelasan pasal 3 ayat 1 yang antara lain menyebutkan bahwa penyelesaian perkara di luar pengadilan atas dasar perdamaian atau melalui arbitrase tetap diperbolehkan, akan tetapi putusan arbiter hanya mempunyai kekuatan eksekutorial setelah memperoleh izin atau perintah untuk dieksekusi dari Pengadilan. ${ }^{3}$

Menurut Black's Law Dictionary: "Arbitration an arrangement for taking anabiding by the judgement of selected persons in some disputed matter, instead of carrying it to establish tribunals of justice, and is intended to avoid the formalities, thedelay, the expense and vexation of ordinary litigation". Menurut Pasal 1 angka 1 Undang Undang Nomor 30 tahun 1999 Arbitrase adalah cara penyelesaian suatu sengketa perdata di luar pengadilan umum yang didasarkan pada perjanjian arbitrase yang dibuat secara tertulis oleh para pihak yang sedang bersengketa.

Dalam perkembangan berikutnya, definisi arbitrase diatur dalam Pasal 1 butir 1 Undang-Undang Nomor 30 Tahun 1999

\footnotetext{
${ }^{3}$ Arbitrase di Indonesia dikenal dengan "perwasitan" secara lebih jelas dapat dilihat dalam UndangUndang Nomor 1 Tahun 1950, yang mengatur tentang acara dalam tingkat banding terhadap putusan-putusan wasit, dengan demikian orang yang ditunjuk mengatasi sengketa tersebut adalah wasit atau biasa disebut "arbiter". Sebelum Undang-Undang Arbitrase berlaku, ketentuan mengenai arbitrase diatur dalam pasal 615 s/d 651 Reglemen Acara Perdata (Rv). Selain itu, pada penjelasan pasal 3 ayat (1) Undang-Undang Nomor 14 Tahun 1970 Tentang Pokok-Pokok Kekuasaan Kehakiman menyebutkan bahwa penyelesaian perkara di luar Pengadilan atas dasar perdamaian atau melalui wasit (arbitrase) tetap diperbolehkan.
} 
tentang Arbitrase bahwa arbitrase adalah cara penyelesaian suatu sengketa perdata di luar peradilan umum yang didasarkan pada perjanjian arbitrase yang dibuat secara tertulis oleh para pihak yang bersengketa. Namun, pengertian yang diberikan tersebut belum menggambarkan pengertian arbitrase secara menyeluruh. Untuk memahami pengertian arbitrase secara menyeluruh diperlukan penjelasan yang diberikan oleh para ahli. Selain itu perlu dijelaskan mengenai syarat-syarat suatu sengketa agar dapat diselesaikan melalui mekanisme arbitrase serta bagaimana prosedur pelaksanaan arbitrase. ${ }^{4}$

Untuk memahami pengertian arbitrase dua orang ahli telah memberikan pengertian mengenai arbitrase yaitu: pertama, Priyatna Abdurrasyid telah menjelaskan arbitrase adalah salah satu solusi alternatif penyelesaian sengketa yang merupakan bentuk tindakan hukum yang diakui oleh undang-undang di mana salah satu pihak atau lebih menyerahkan sengketanya ketidaksefahamannya ketidaksepakatannya dengan satu pihak lain atau lebih kepada satu orang (arbiter) atau lebih (arbiter - arbiter - majelis) ahli yang professional, yang akan bertindak sebagai hakim / peradilan swasta yang akan menerapkan tata cara hukum negara yang berlaku atau menerapkan tata cara hukum perdamaian yang telah disepakati bersama oleh para pihak terdahulu untuk sampai kepada putusan yang final mengikat. ${ }^{5}$

Kedua, R. Subekti menjelaskan bahwa arbitrase adalah penyelesaian suatu perselisihan (perkara) oleh seorang atau beberapa orang wasit (arbiter) yang bersama-sama ditunjuk oleh para pihak yang berperkara dengan tidak diselesaikan lewat Pengadilan. ${ }^{6}$ Berdasarkan pendapat kedua ahli tersebut, dapat disimpulkan pengertian dari arbitrase, yaitu: Proses penyelesaian sengketa diantara

${ }^{4}$ Pasal 1 butir 1 Undang-Undang Nomor 30 Tahun 1999 tentang Arbitrase.

${ }^{5}$ Priyatna Abdurrasyid, Arbitrase: Solusi Alternatif Penyelesaian Sengketa Perdata, dalam http://id.shvoong.com/law-and-politics/1908998-keunggulan-dankelemahan-arbitrase/, diakses tanggal 10 Septmeber 2013.

${ }^{6}$ R. Subekti, Arbitrase Perdagangan (Bandung: Bina Cipta. 1979), hlm. 3. para pihak yang mengadakan perjanjian untuk menunjuk seorang atau lebih sebagai arbiter dalam memutus perkara yang sifat putusannya adalah final mengikat.

Sedangkan yang ketiga, H.M.N. Purwosutjipto menggunakan istilah perwasitan untuk arbitrase yang diartikan sebagai suatu peradilan perdamaian, di mana para pihak bersepakat agar perselisihan mereka tentang hak pribadi yang dapat mereka kuasai sepenuhnya diperiksa dan diadili oleh hakim yang tidak memihak yang ditunjuk oleh para pihak sendiri dan putusannya mengikat bagi keduabelah pihak.?

Mengacu kepada pendapat tiga tokoh di atas, pada dasarnya arbitrase adalah suatu bentuk khusus pengadilan. Aspek penting yang bisa membedakan pengadilan dan arbitrase adalah bila jalur pengadilan (judicial settlement) menggunakan satu peradilan permanen atau standing court, sedangkan arbitrase menggunakan forum tribunal yang dibentuk khusus untuk kegiatan tersebut. Dalam arbitrase, arbitrator bertindak sebagai "hakim" dalam mahkamah arbitrase, sebagaimana hakim permanen, walaupun hanya untuk kasus yang sedang ditangani.

\section{Obyek dan Jenis Arbitrase}

Objek perjanjian arbitrase (sengketa yang akan diselesaikan di luar pengadilan melalui lembaga arbitrase dan atau lembaga alternatif penyelesaian sengketa lainnya) menurut Pasal 5 ayat 1 Undang Undang Nomor 30 Tahun 1999 Tentang Arbitrase) hanyalah sengketa di bidang perdagangan dan mengenai hak yang menurut hukum dan peraturan perundang-undangan dikuasai sepenuhnya oleh pihak yang bersengketa.

Adapun kegiatan dalam bidang perdagangan antara lain: perniagaan, perbankan, keuangan, penanaman modal, industri dan hak milik intelektual. Sementaraitu Pasal 5 (2) Undang-Undang Arbitrase memberikan perumusan negatif bahwa sengketa-sengketa yang dianggap tidak dapat diselesaikan

${ }^{7}$ Penjelasan H.M.N. Purwosutjipto, Arbitrase dan Penyelesaian Sengketa Perdata, dalam http://dodiksetiawan.wordpress.com/2009/04/14/definisi-arbitrase/, diakses tanggal 10 September 2013. 
melalui arbitrase adalah sengketa yang menurut peraturan perundang-undangan tidak dapat diadakan perdamaian sebagaimana diatur dalam KUH Perdata Buku III bab kedelapan belas Pasal 1851 s.d 1854 .

Arbitrase juga dapat berupa arbitrase sementara (ad hoc) maupun arbitrase melalui badan permanen (institusi). Arbitrase $\mathrm{Ad}$ hoc dilaksanakan berdasarkan aturan-aturan yang sengaja dibentuk untuk tujuan arbitrase, misalnya Undang-Undang Nomor 30 Tahun 1999 Tentang Arbitrase dan Alternatif Penyelesaian Sengketa atau UNCITRAL Arbitarion Rules. Pada umumnya arbitrase Ad hoc ditentukan berdasarkan perjanjian yang menyebutkan penunjukan majelis arbitrase serta prosedur pelaksanaan yang disepakati oleh para pihak. Penggunaan model arbitrase Ad hoc perlu disebutkan dalam sebuah klausul arbitrase.

Sistem arbitrase institusi adalah suatu lembaga permanen yang dikelola oleh berbagai badan arbitrase berdasarkan aturanaturan yang mereka tentukan sendiri. Saat ini dikenal berbagai aturan arbitrase yang dikeluarkan oleh badan-badan arbitrase seperti Badan Arbitrase Nasional Indonesia (BANI), atau yang internasional seperti The Rules of Arbitration dari The International Chamber of Commerce (ICC) di Paris, The Arbitration Rules dari The International Centre for Settlement of Investment Disputes (ICSID) di Washington. Badan-badan tersebut mempunyai peraturan dan sistem arbitrase sendiri-sendiri.

Sedangkan BANI (Badan Arbitrase Nasional Indonesia) memberi standar klausul arbitrase sebagai berikut: "Semua sengketa yang timbul dari perjanjian ini, akan diselesaikan dan diputus oleh Badan Arbitrase Nasional Indonesia (BANI) menurut peraturan-peraturan prosedur arbitrase BANI, yang keputusannya mengikat kedua belah pihak yang bersengketa, sebagai keputusan dalam tingkat pertama dan terakhir".

Standar klausul arbitrase UNCITRAL (United Nation Comission of International Trade Law) adalah sebagai berikut: "Setiap sengketa, pertentangan atau tuntutan yang terjadi atau sehubungan dengan perjanjian ini, atau wan prestasi, pengakhiran atau sah tidaknya perjanjianakan diselesaikan melalui arbitrase sesuai dengan aturan-aturan UNCITRAL.".

Dalam hal ini, penulis mendukung penjelasan yang diberikan oleh Priyatna Abdurrasyid, Ketua BANI, yang memeriksa pertama kali adalah klausul arbitrase, bahwa ada atau tidaknya, sah atau tidaknya klausul arbitrase, ia akan menentukan apakah suatu sengketa akan diselesaikan lewat jalur arbitrase. Bisa saja klausul atau perjanjian arbitrase dibuat setelah sengketa timbul. Dengan demikian, pada dasarnya arbitrase dapat berwujud dalam dua bentuk, yaitu: (1) Factum de compromitendo, yaitu klausa arbitrase yang tercantum dalam perjanjian tertulis yang dibuat para pihak sebelum timbul sengketa; dan (2) Akta Kompromis, yaitu suatu perjanjian arbitrase tersendiri yang dibuat para pihak setelah timbul sengketa. ${ }^{8}$

Setiap bentuk perjanjian arbitrase dapat dinyatakan batal, apabila dalam proses penyelesaian sengketa terjadi peristiwa-peristiwa sebagai berikut: (1) salah satu dari pihak yang bersengketa meninggal dunia; (2) salah satu dari pihak yang bersengketa mengalami kebangkrutan, inovasi (pembaharuan utang), dan insolvensi; (3) pewarisan; (4) hapusnya syarat-syarat perikatan pokok; (5) pelaksanaan perjanjian arbitrase dialihtugaskan pada pihak ketiga dengan persetujuan pihak yang melakukan perjanjian arbitrase tersebut; dan (6) berakhirnya atau batalnya perjanjian pokok.

Berdasarkan uraian di atas, penulis merumuskan bahwa pada dasarnya arbitrase dapat berwujud dalam 2 (dua) bentuk, yaitu: pertama, klausula arbitrase yang tercantum dalam suatu perjanjian tertulis yang dibuat para pihak sebelum timbul sengketa (Factum de Compromitendo); dan kedua, suatu perjanjian Arbitrase tersendiri yang dibuat para pihak setelah timbul sengketa ( $A k$ ta Kompromis). Arbitase hanya dapat diterapkan untuk masalah-masalah perniagaan. Bagi pengusaha, arbitrase merupakan pilihan yang paling menarik guna menyelesaikan

\footnotetext{
${ }^{8}$ Iqbal Amaludin, Penyelesaian Sengketa Hukum Melalui Arbitrase, dalam http://iqbalamaludin.blogspot.com/2013/04/v-behaviorurldefaultvmlo.html, diakses tanggal 10 Oktober 2013.
} 
sengketa sesuai dengan keinginan dan kebutuhan mereka.

\section{Syarat, Prosedur, dan Mekanisme Arbitrase}

Berdasarkan pengertian arbitrase, perlu ditegaskan syarat utama dari berlangsungnya suatu arbitrase adalah perjanjian dari para pihak untuk menyelesaikan sengketa melalui mekanisme arbitrase. Maksudnya, perjanjian dapat lahir sebelum adanya sengketa atau sesudah adanya sengketa. Jika arbitrase dijalankan tanpa adanya perjanjian arbitrase di antara para pihak yang bersengketa, maka itu bukanlah arbitrase.

Dengan adanya perjanjian arbitrase, $\mathrm{Pe}$ ngadilan Negeri tidak berwenang untuk mengadili sengketa para pihak tersebut. Pelaksanaan perjanjian arbitrase tidak mempersoalkan masalah pelaksanaan perjanjian, akan tetapi yang dipermasalahkannya adalah cara dan lembaga apa yang berwenang menyelesaikan perselisihan yang terjadi antara pihak yang berjanji. Perjanjian arbitrase harus memenuhi syarat yaitu persetujuan mengenai perjanjian arbitrase tersebut harus dibuat dalam suatu perjanjian tertulis yang ditandatangani oleh para pihak. ${ }^{9}$

Perjanjian arbitrase sering juga disebut sebagai klausul arbitrase yang berada dalam badan perjanjian pokok. Hal tersebut dapat diartikan suatu perjanjian pokok diikuti atau dilengkapi dengan persetujuan mengenai pelaksanaan arbitrase. Klausul arbitrase ini diletakkan di dalam perjanjian pokok sehingga disebut sebagai perjanjian aksesori. Keberadaannya hanya sebagai tambahan dari perjanjian pokok, sehingga tidak berpengaruh terhadap pemenuhan perjanjian pokok. Tanpa adanya perjanjian pokok, perjanjian arbitrase ini tidak bisa berdiri sendiri, karena sengketa atau perselisihan timbul akibat adanya perjanjian pokok.

Timbul suatu konsekuensi dari sifat perjanjian arbitrase yang merupakan perjanjian aksesori. Dengan sifat aksesorinya, suatu perjanjian arbitrase tidak akan hapus karena

${ }^{9}$ Paustinus Siburian, Arbitrase Online (Alternatif Penyelesaian Sengketa Perdagangan Secara Elektronik) (Jakarta: Djambatan. 2004), hlm. 42. berakhirnya atau batalnya perjanjian pokok. Selain itu, perjanjian arbitrase juga tidak akan hapus oleh keadaan meninggalnya para pihak, bangkrutnya salah satu pihak, novasi, insolvensi salah satu pihak, pewarisan, dan pengalihan perjanjian kepada pihak ketiga atas persetujuan pihak yang mengadakan perjanjian arbitrase.

Prosedur arbitrase perlu dipahami untuk melihat apakah prosedur arbitrase konvensional seperti yang terdapat di dalam Undang-undang Nomor 30 Tahun 1999 dapat diterapkan menjadi mekanisme online. Secara garis besar, prosedur arbitrase dapat dibagi ke dalam tiga tahap sebagai berikut: ${ }^{10}$

1. Prosedur sebelum dengar pendapat. Penyelesaian sengketa melalui arbitrase, diawali dengan prosedur sebelum dengar pendapat yang terdiri dari beberapa tahap sebagai berikut.

a. Pemberitahuan kepada arbiter tentang penunjukannya. Langkah pertama yang perlu dilakukan untuk melakukan arbitrase adalah pemberitahuan secara tertulis kepada seorang ahli bahwa ia telah dipilih sebagai arbiter untuk menyelesaikan suatu sengketa;

b. Persiapan arbiter. Hal penting yang perlu diperhatikan oleh arbiter adalah penunjukkannya sudah dilakukan berdasarkan hukum sesuai dengan peraturan yang berlaku;

c. Pemeriksaaan pendahuluan. Berdasarkan praktek, biasanya arbiter mengadakan pertemuan terlebih dahulu dengan para pihak sebelum mengadakan dengar pendapat secara resmi;

d. Prosedur pelaksanaan tugas arbiter. Berdasarkan Undang-undang Nomor 30 Tahun 1999, arbiter berwenang untuk memerintahkan dan melakukan introgasi dalam proses dengar pendapat. Dalam proses tersebut, arbiter dapat bersikap aktif, yaitu arbiter bertindak men-

\footnotetext{
${ }^{10} \mathrm{M}$. Yahya Harahap, Arbitrase Ditinjau dari: Reglemen Acara Perdata (Rv), Prosedur BANI, International Centre for the Settlement of Investment Dispute (ICSID), UNICITRAL Arbitration Rules, Convention on the Recognition and Enforcement of Foreing Arbitral Award, PERMA No. 1 Tahun 1990 (Jakarta: Pustaka Kartini. 1991), hlm. 97.
} 
cari data. Namun, arbiter juga dapat bersikap pasif, yaitu para pihak lah yang menyampaikan data-data sedangkan arbiter cukup mendengarkan saja;

e. Menentukan waktu dan dengar pendapat. Jika ada salah satu pihak yang tidak datang pada saat dengar pendapat, maka arbiter tetap dapat melakukan dengar pendapat tersebut;

f. Komunikasi perorangan para pihak. Apabila salah satu pihak dalam proses arbitrase menghubungi arbiter tanpa sepengetahuan pihak lain, arbiter wajib menolaknya.

2. Prosedur pada waktu dengar pendapat. Arbiter memiliki kedudukan sebagai seorang hakim berdasarkan adanya kesepakatan penunjukan para pihak yang bersengketa. Penunjukan oleh para pihak ini memberikan wewenang kepada arbiter untuk dapat memutus berdasarkan fakta yang diberikan kepadanya. Pada saat proses arbitrase berlangsung pihak ketiga atau pihak lain (umum) tidak diperbolehkan hadir dalam proses. Hal ini merupakan cerminan dari sifat arbitrase yang menjaga kerahasian para pihak yang bersengketa.

3. Pelaksanaan putusan. Dalam melaksanakan putusan arbitrase ada tata cara pelaksanaan yang harus ditempuh. Berdasarkan Pasal 59 Undang-undang Nomor 30 Tahun 1999, tata cara pelaksanaan pokokpokok di dalam putusan tergantung pada telah didaftarkannya di pengadilan atau belum.

Dalam kaitannya dengan institusi pengadilan, lembaga arbitrase masih memiliki ketergantungan pada pengadilan, misalnya dalam hal pelaksanaan putusan arbitrase. Ada keharusan untuk mendaftarkan putusan arbitrase di pengadilan negeri. Hal ini menunjukkan bahwa lembaga arbitrase tidak mempunyai upaya pemaksa terhadap para pihak untuk menaati putusannya, terutama dalam perkara perdata. ${ }^{11}$

\footnotetext{
${ }^{11}$ Budhy Budiman, Mencari Model Ideal Penyelesaian Sengketa: Kajian Terhadap Praktik Peradilan Perdata dan Undang-Undang Nomor 30 Tahun 1999, artikel
}

Peranan pengadilan dalam penyelenggaraan arbitrase berdasar Undang-Undang Arbitrase antara lain mengenai penunjukkan arbiter atau majelis arbiter dalam hal para pihak tidak ada kesepakatan pasal 14 ayat (3) dan dalam hal pelaksanaan putusan arbitrase nasional maupun internasional yang harus dilakukan melalui mekanisme sistem peradilan yaitu pendaftaran putusan tersebut dengan menyerahkan salinan autentik putusan. Bagi arbitrase internasional mengambil tempat di Pengadilan Negeri Jakarta Pusat

Kemudian dalam pelaksanaan atau mekanismenya, arbitrase dibagi dua yaitu arbitrase nasional dan arbitrase internasional. ${ }^{12}$

1. Arbitrase Nasional

Pelaksanaan putusan arbitrase nasional diatur dalam Pasal 59-64 Undang-Undang Nomor 30 Tahun 1999. Pada dasarnya para pihak harus melaksanakan putusan secara sukarela. Agar putusan arbitrase dapat dipaksakan pelaksanaanya, putusan tersebut harus diserahkan dan didaftarkan pada kepaniteraan pengadilan negeri, dengan mendaftarkan dan menyerahkan lembar asli atau salinan autentik putusan arbitrase nasional oleh arbiter atau kuasanya ke panitera pengadilan negeri, dalam waktu 30 (tiga puluh) hari setelah putusan arbitase diucapkan. Putusan Arbitrase nasional bersifat mandiri, final dan mengikat.

Putusan Arbitrase nasional bersifat mandiri, final dan mengikat (seperti putusan yang mempunyai kekeuatan hukum tetap) sehingga Ketua Pengadilan Negeri tidak diperkenankan memeriksa alasan atau pertimbangan dari putusan arbitrase nasional tersebut. Kewenangan memeriksa yang dimiliki Ketua Pengadilan Negeri, terbatas pada pemeriksaan secara formal terhadap putusan arbitrase nasional yang dijatuhkan oleh arbiter atau majelis arbitrase. Berdasar Pasal 62 Undang-Undang Nomor 30 Tahun 1999 sebelum memberi perintah pelaksanaan, Ketua

dalam http://www.uika-bogor.ac.id/juro5.htm, diakses 10 September 2013.

${ }^{12}$ Gatot Soemartono, Arbitrase dan Mediasi di Indonesia (Jakarta: PT Gramedia Pustaka Utama. 2006), hlm. 3 . 
Pengadilan memeriksa dahulu apakah putusan arbitrase memenuhi Pasal 4 dan pasal 5 (khusus untuk arbitrase internasional). Bila tidak memenuhi maka, Ketua Pengadilan Negeri dapat menolak permohonan arbitrase dan terhadap penolakan itu tidak ada upaya hukum apapun.

\section{Arbitrase Internasional}

Semula pelaksanaan putusan-putusan arbitrase asing di indonesia lebih banyak didasarkan pada ketentuan Konvensi Jenewa 1927, dan pemerintah Belanda yang merupakan negara peserta konvensi tersebut menyatakan bahwa Konvensi berlaku juga diwilayah Indonesia. Pada tanggal 10 Juni 1958 di New York ditandatangani UN Convention on the Recognition and Enforcement of Foreign Arbitral Award. Indonesia telah mengaksesi Konvensi New York tersebut dengan Keputusan Presiden Nomor 34 Tahun 1981 pada 5 Agustus 1981 dan didaftar di Sekretaris PBB pada 7 Oktober 1981.

Pada 1 Maret 1990 Mahkamah Agung mengeluarkan Peraturan Mahkamah Agung Nomor 1 tahun 1990 tentang Tata Cara Pelaksanaan Putusan arbitrase asing sehubungan dengan disahkannya konvensi New York 19$58 \mathrm{M}$. Dengan adanya Perma tersebut hambatan bagi pelaksanaan putusan arbitrase asing di Indonesia yang seharusnya bisa diatasi. Tetapi dalam prakteknya kesulitankesulitan masih ditemui dalam eksekusi putusan arbitrase asing.

\section{E. Manfaat Arbitrase dalam Proses Pene- gakan Hukum}

Penegakan hukum (law enforcement) merupakan aspek terpenting yang mendukung supremasi hukum (supremacy of law) dalam proses pembangunan bangsa. Penegakan hukum dan supremasi hukum dalam konteks negara hukum bukan semata-mata menjadi tugas dan kewajiban aparat penegak hukum, tetapi juga menjadi tugas dan kewajiban setiap individu dalam masyarakat. Hal ini sangat penting bagi tujuan terciptanya keadilan dan kedamaian di tengah-tengah masyarakat berlandaskan penghargaan terhadap Hak Asasi Manusia.

Penegakan hukum adalah proses pemungsian norma-norma hukum secara nyata sebagai pedoman perilaku atau hubunganhubungan hukum dalam kehidupan bermasyarakat, berbangsa dan bernegara. ${ }^{13}$ Sedangkan Purnadi Purbacaraka, menjelaskan penegakan hukum diartikan sebagai kegiatan menyerasikan nilai-nilai yang terjabarkan dalam kaidah-kaidah/pandangan-pandangan menilai yang mantap dan mengejewantah dari sikap tindak sebagai rangkaian penjabaran nilai tahap akhir, untuk menciptakan, memelihara, dan mempertahankan kedamaian pergaulan hidup. ${ }^{14}$

Definisi lainnya dikemukakan oleh Liliana Tedjosaputro. ${ }^{15}$ la menjelaskan bahwa penegakan hukum bukan hanya mencakup law enforcement, tetapi juga peace maintenance, oleh karena penegakan hukum merupakan proses penyerasian antara nilai-nilai, kaidahkaidah dan pola prilaku nyata, yang bertujuan untuk mencapai kedamaian dan keadilan. Tugas utama penegakan hukum adalah untuk mewujudkan keadilan, yang karenanya, dengan penegakan hukum itulah hukum menjadi kenyataan. Tanpa penegakan hukum, maka hukum tidak ubahnya hanya merupakan rumusan tekstual yang tidak bernyali atau hukum yang mati.

Pendapat yang hampir sama dijelaskan oleh Mirza Riviera bahwa penegakan hukum adalah proses dilakukannya upaya untuk tegaknya atau berfungsinya norma-norma hukum secara nyata sebagai pedoman perilaku dalam lalu-lintas atau hubungan-hubungan hukum dalam kehidupan bermasyarakat dan bernegara. ${ }^{16}$ Ditinjau dari sudutnya penegak-

\footnotetext{
${ }^{13}$ Penulis mengutip definisi yang dikemukakan oleh Sasmitasari, Pengertian Penegakan Hukum, artikel dalam http://sasmitasmansa.wordpress.com/2011/12/07/pengertian-penegakan-hukum, diakses tanggal 10 Oktober 2013.

${ }^{14}$ Purnadi Purbacaraka menjelaskan pengertian penegakan hukum sebagaimana dikutip dari http://hukum-on.blogspot.com/2012/06/pengertian-supremasihukum-dan.html, diakses 10 Oktober 2013.

${ }^{15}$ Liliana Tedjosaputro, menjelaskan pengertian penegakan hukum sebagaimana dikutip dari http://hukum-on.blogspot.com/2012/06/pengertian-supremasi-hukum-dan.html, diakses 6 November 2012.

${ }^{16}$ Mirza Riviera, Penegakan Hukum di Indonesia, artikel dalam http://viarviorviera. blogspot.com/2012/03/penegakan-hukum-di-indonesia.html, diakses tanggal 10 November 2012.
} 
kan hukum dibagi menjadi dua yaitu dari sudut subjektif dan sudut objektif.

Dari sudut subjeknya penegakan hukum itu dapat dilakukan oleh subjek yang luas dan dapat pula diartikan sebagai upaya penegakan hukum oleh subjek dalam arti yang terbatas atau sempit. Dalam arti luas, proses penegakan hukum itu melibatkan semua subjek hukum dalam setiap hubungan hukum. Siapa saja yang menjalankan aturan normatif atau melakukan sesuatu atau tidak melakukan sesuatu dengan mendasarkan diri pada norma aturan hukum yang berlaku, berarti dia menjalankan atau menegakkan aturan hukum. Dalam arti sempit, dari segi subjeknya itu, penegakan hukum itu hanya diartikan sebagai upaya aparatur penegakan hukum tertentu untuk menjamin dan memastikan bahwa suatu aturan hukum berjalan sebagaimana seharusnya.

Sedangkan ditinjau dari sudut objeknya, yaitu dari segi hukumnya. Dalam hal ini, pengertiannya juga mencakup makna yang luas dan sempit. Dalam arti luas, penegakan hukum itu mencakup pula nilai-nilai keadilan yang terkandung di dalamnya bunyi aturan formal maupun nilai-nilai keadilan yang hidup dalam masyarakat. Tetapi, dalam arti sempit, penegakan hukum itu hanya menyangkut penegakan peraturan yang formal dan tertulis saja. Karena itu, penerjemahan perkataan law enforcement ke dalam bahasa Indonesia dalam menggunakan perkataan penegakan hukum dalam arti luas dan dapat pula digunakan istilah 'penegakan peraturan' dalam arti sempit.

Membicarakan kelebihan dan kekurangan arbitrase tidak terlepas dari sifat arbitrase sebagai alternatif penyelesaian sengketa yang proses proseduralnya bersifat adjudikasi hal ini sejalan dengan pendapat yang mengatakan bahwa "Arbitration is the most formalized alternative to the court adjudication of disputes." Akan dijelaskan mengenai kelebihan arbitrase jika dibandingkan dengan proses litigasi biasa sebagai berikut: ${ }^{17}$

${ }^{17}$ Pan Mohammad Faiz, Klausul Arbitrase dan Pengadilan dalam Penyelesaian Sengketa, artikel dalam http://jurnalhukum.blogspot.com/2006/09/klausul-
1. Konfidensial. Artinya kerahasiaan para pihak yang bersengketa dalam arbitrase akan dijaga, sehingga dampak negatif yang timbul dari terlibatnya para pihak dalam suatu perselisihan tidak menjatuhkan kredibilitas para pihak. Hal ini terkait dengan nama baik para pihak yang saat ini merupakan salah satu aset perusahaan yang harus dilindungi.

Tercemarnya nama baik suatu pihak dapat menyebabkan kerugian yang besar bagi pihak tersebut. Nama baik suatu pihak biasanya akan tercemar apabila pihak tersebut mengalami suatu perselisihan yang diketahui oleh publik. Dalam proses litigasi dikenal adanya asas terbuka untuk umum, artinya siapa saja dapat menyaksikan proses persidangan yang sedang berlangsung. Hal ini tentu akan berdampak buruk bagi pihak yang mengalami sengketa dan penyelesaian sengketanya melalui jalur litigasi lalu proses persidangannya diekspose kepada publik. Dengan sendirinya nilai kepercayaan publik kepadanya akan berkurang.

Melalui arbitrase, konfidensial para pihak tetap terjaga. Berbeda dengan pengadilan umum, arbiter tidak diwajibkan untuk menyampaikan putusannya secara terbuka. Tidak hanya dalam penyampaian putusan, berdasarkan Pasal 27 UndangUndang Nomor 30 Tahun 1999 dikatakan bahwa: "Semua pemeriksaan sengketa oleh arbiter atau majelis arbitrase dilakukan secara tertutup." Dengan demikian maka nilai kerahasiaan para pihak akan terjaga.

2. Biaya untuk arbitrase lebih murah dari biaya litigasi dan penyelesaian sengketanya lebih cepat. Pendapat mengenai biaya ini masih diperdebatkan, tidak selamanya biaya untuk arbitrase lebih murah dari biaya litigasi. Sebagai contoh apabila terjadi sengketa antara pengusaha asal Indonesia dengan pengusaha asal Vietnam lalu mereka sepakat menunjuk arbiter yang berada di New York untuk menyelesaikan sengketanya di Singapore. Maka perlu di-

arbitrase-dan-pengadilan_18.html, diakses tanggal 10 September 2013. 
hitung berapa yang harus dikeluarkan untuk pendaftaran perkara, biaya akomodasi arbiter, biaya akomodasi para pihak, honorarium untuk arbiter, dan biaya saksi ahli seandainya digunakan. Tentu para pihak akan mengeluarkan biaya yang cukup besar untuk arbitrase tersebut.

Di sisi lain, bagi seorang pengusaha yang membutuhkan kepastian hukum dalam sengketa yang menyangkut usahanya, biaya tersebut tidak seberapa dibandingkan ia harus berlama-lama menyelesaikan perkara di pengadilan karena harus menunggu urutan perkaranya disidangkan dan ia tidak bisa melanjutkan usaha. Bagi mereka semakin cepat masalah sengketanya selesai dan memperoleh kekuatan hukum, semakin cepat pula untuk kembali berusaha mendapatkan keuntungan, sehingga secara umum biaya akan lebih murah. Penyelesaian sengketa dalam arbitrase lebih cepat dari proses litigasi karena dalam arbitrase para pihak tidak usah menunggu perkaranya disidangkan. Para pihak bisa langsung memilih arbiter untuk menyelesaikan sengketa mereka, sehingga tidak dibutuhkan waktu tunggu sebagaimana pada proses litigasi.

Selain itu, dalam penyelesaian sengketa dapat dilakukan kapan saja berdasarkan kesepakatan para pihak sehingga sangat mungkin dalam satu minggu dilakukan beberapa kali proses pemeriksaan sengketa. Hal ini berbeda dengan proses litigasi. Dalam proses litigasi, Majelis Hakim tidak hanya memeriksa satu perkara, sehingga dalam satu minggu perkara kemungkinan besar hanya diperiksa satu kali. Dengan kata lain, keterlambatanketerlambatan yang bersifat prosedural dan administratif dapat dihindari.

3. Para pihak dapat memilih arbiter berdasarkan keyakinannya mempunyai pengetahuan, pengalaman, serta latar belakang yang memadai mengenai masalah yang disengketakan.

Dalam proses litigsi, para pihak tidak bisa memilih hakim yang akan memutuskan sengketa melainkan sudah ditentukan oleh Ketua Pengadilan Negeri berdasarkan penetapannya. Kelemahan dari pene- tapan tersebut adalah kemampuan Hakim yang terbatas pada pengetahuan hukum sementara pengetahuan lain hanya dikuasainya secara umum.

Dengan arbitrase, para pihak dapat memilih arbiter yang memang menguasai bidang atau pengetahuan yang sedang dipersengketakan, sehingga putusannya lebih komprehensif dan profesional.

4. Para pihak dapat menentukan pilihan hukum untuk menyelesaikan sengketa, proses, dan tempat penyelenggaraan arbitrase. Kelebihan ini dirasakan oleh pihak yang merasa akan mengalami diskriminasi apabila bersengketa di tempat kedudukan hukum pihak lawannya.

Pada kenyataannya apa yang disebutkan sebelumnya tidak semuanya benar, sebab di negara tertentu proses peradilan dapat lebih cepat daripada proses arbitrase. Satu-satunya kelebihan arbitrase terhadap pengadilan adalah sifat kerahasiannya karena keputusannya tidak dipublikasikan. Namun, penyelesaian sengketa melalui arbitrase masih lebih diminati daripada litigasi, terutama untuk kontrak bisnis bersifat internasional. Selain itu terdapat juga kelemahan dari proses arbitrase sebagai berikut:

1. Berdasarkan Pasal 1 butir 1 jo. Pasal 5 Undang-Undang Nomor 30 Tahun 1999, sengketa yang dapat diselesaikan melalui arbitrase terbatas pada sengketa perdata, khususnya mengenai perdagangan dan mengenai hak yang menurut hukum dan peraturan perundang-undangan dikuasai sepenuhnya oleh pihak yang bersengketa. Dengan demikian tidak semua perkara bisa diselesaikan melalui arbitrase. Meskipun perkara yang ada berupa sengketa perdata, belum tentu juga dapat diselesaikan dengan arbitrase;

2. Meskipun putusan arbitrase bersifat final dan mengikat, proses arbitrase tetap membutuhkan Pengadilan Negeri untuk melaksanakan proses eksekusinya;

3. Pelaksanaan arbitrase asing dapat terhambat akibat adanya asas nasionalitas dan asas resiprositas. Asas nasionalitas menyatakan bahwa untuk menentukan dan menilai apakah suatu putusan arbitrase dapat dikualifikasikan sebagai 
putusan arbitrase asing, harus diuji menurut ketentuan hukum RI.

Keunggulan arbitrase dapat dirumuskan melalui penjelasan umum Undang-Undang Nomor 30 tahun 1999 bahwa beberapa keunggulan penyelesaian sengketa melalui arbitrase dibandingkan dengan pranata peradilan. ${ }^{18}$ Keunggulan itu antara lain:

1. Kerahasiaan sengketa para pihak terjamin;

2. Keterlambatan yang diakibatkan karena hal prosedural dan administratif dapat dihindari;

3. Para pihak dapat memilih arbiter yang berpengalaman, memiliki latar belakang yang cukup mengenai masalah yang disengketakan, serta jujur dan adil;

4. Para pihak dapat menentukan pilihan hukum untuk penyelesaian masalahnya, para pihak dapat memilih tempat penyelenggaraan arbitrase ;

5. Putusan arbitrase merupakan putusan yang mengikat para pihak melalui prosedur sederhana ataupun dapat langsung dilaksanakan.

Para ahli juga mengemukakan pendapatnya mengenai keunggulan arbitrase. Menurut Subekti, bagi dunia perdagangan atau bisnis, penyelesaian sengketa lewat arbitrase atau perwasitan, mempunyai beberapa keuntungan yaitu bahwa dapat dilakukan dengan cepat, oleh para ahli, dan secara rahasia. Sedangkan H.M.N. Purwosutjipto mengemukakan arti pentingnya peradilan wasit (arbitrase) adalah:

1. Penyelesaian sengketa dapat dilaksanakan dengan cepat;

2. Para wasit terdiri dari orang-orang ahli dalam bidang yang dipersengketakan, yang diharapkan mampu membuat putusan yang memuaskan para pihak;

3. Putusan akan lebih sesuai dengan perasaan keadilan para pihak;

4. Putusan peradilan wasit dirahasiakan, sehingga umum tidak mengetahui tentang kelemahan-kelemahan perushaan yang bersangkutan. Sifat rahasia pada putusan

\footnotetext{
${ }^{18}$ Penjelasan Umum Undang-Undang Nomor 30 tahun 1999 tentang beberapa keunggulan penyelesaian sengketa melalui arbitrase.
}

perwasitan inilah yang dikehendaki oleh para pengusaha.

Di samping keunggulan arbitrase seperti tersebut diatas, arbitrase juga memiliki kelemahan arbitrase. Dari praktek yang berjalan di Indonesia, kelemahan arbitrase adalah masih sulitnya upaya eksekusi dari suatu putusan arbitrase, padahal pengaturan untuk eksekusi putusan arbitrase nasional maupun internasional sudah cukup jelas.

Meskipun penyelesaian melalui arbitrase diyakini memiliki keunggulan-keunggulan dibandingkan dengan jalur pengadilan, tetapi penyelesaian melalui Arbitrase juga memiliki kelemahan-kelemahan. Beberapa kelemahan dari Arbitrase dan ADR antara lain:

1. Arbitrase belum dikenal secara luas, baik oleh masyarakat awam, maupun masyarakat bisnis, bahkan oleh masyarakat akademis sendiri. Sebaga icontoh masyarakat masih banyak yang belum mengetahui keberadaan dan kiprah dari lembagalembaga seperti BANI, BASYARNAS dan $\mathrm{P} 3 \mathrm{Bl}$;

2. Masyarakat belum menaruh kepercayaan yang memadai, sehingga enggan memasukkan perkaranya kepada lembaga-lembaga Arbitrase. Hal ini dapat dilihat dari sedikitnya perkara yang diajukan dan diselesaikan melalui lembaga-lembaga Arbitrase yang ada;

3. Lembaga Arbitrase dan ADR tidak mempunyai daya paksa atau kewenangan melakukan eksekusi putusannya;

4. Kurangnya kepatuhan para pihak terhadap hasil-hasil penyelesaian yang dicapai dalam Arbitrase, sehingga mereka seringkali mengingkari dengan berbagai cara, baik dengan teknik mengulur-ulur waktu, perlawanan, gugatan pembatalan dan sebagainya;

5. Kurangnya para pihak memegang etika bisnis. Sebagai suatu mekanis meextra judicial, Arbitrase hanya dapat bertumpu di atas etika bisnis, seperti kejujuran dan kewajaran.

Jika mengacu kepada asas resiprositas dalam proses penegakan hukum, penulis berpendapat bahwa tidak semua putusan arbitrase asing dapat diakui (recognize) dan dieksekusi (enforcement). Oleh karena itu, 
putusan arbitrase asing yang diakui dan dapat dieksekusi hanya terbatas pada putusan yang diambil di negara asing yang mempunyai ikatan bilateral dengan negara RI dan terkait bersama dengan negara RI dalam suatu konvensi internasional. Adanya asas nasionalitas dan resiprositas ini menyebabkan tidak adanya kepastian hukum bagi sengketa yang diputus oleh arbitrase asing yang tidak memenuhi persyaratan kedua asas tersebut.

\section{F. Contoh Penyelesaian Sengketa} Ekonomi Syariah Melalui Arbitrase Antara PT. Bank Syari'ah Mandiri Melawan PT. Atriumasta Sakti dan Majelis Arbiter Basyarnas

Putusan Mahkamah Agung Nomor: 56 PK/AG/2011 membahas perkara tentang sengketa ekonomi syariah dalam yang diajukan oleh PT. Bank Syari'ah Mandiri sebagai Pemohon Peninjauan Kembali/Termohon Banding/Pemohon melawan PT. Atriumasta Sakti dan Majelis Arbiter Basyarnas, yang memeriksa dan memutus perkara Nomor: 16/Tahun 2008/BASYARNAS/Ka.Jak sebagai Para Termohon Peninjauan Kembali/Pemohon Banding/Termohon I dan II. Majelis Hakim PK ini diketuai oleh Habiburrahman yang beranggotakan Abdul Manan dan Hamdan.

Latar belakang penyelesaian perkara tersebut sampai pada tahap Peninjauan Kembali adalah dalam perkara arbitrase untuk mengajukan pembatalan putusan arbitrase ke Pengadilan Agama dengan alasan-alasan bahwa Amar putusan Basyarnas (Termohon Kasasi II) dinilai tidak logis dengan Menyatakan Pemohon Kasasi melakukan cidera janji dan Menyatakan batal demi hukum Akad Pembiayaan Murabahah Nomor 53 tanggal 23 Februari yang dibuat Efran Yuniarto, S.H. (Notaris di Jakarta).

Dalam penyelesaiannya di pengadilan tingkat pertama, Pengadilan Agama Jakarta Pusat dalam Putusan Nomor: 792/Pdt.G/2009/PA.JP tanggal 10 Desember $2009 \mathrm{M}$, mengabulkan permohonan Pemohon dan telah membatalkan Putusan Basyarnas Nomor 16/Tahun 2008/BASYARNAS/Ka.Jak yang diputuskan pada tanggal 16 September
2009 dan yang telah terdaftar di Kepaniteraan Pengadilan Agama Jakarta Pusat sesuai akta Pendaftaran Nomor: 01/Basyarnas/2009/PA.JP tanggal 12 Oktober 2009.

Kemudian pada Tingkat Banding, Putusan Mahkamah Agung RI Nomor: 188 K/AG/2010 tanggal o9 Juni 2010 yang telah berkekuatan hukum tetap dan membatalkan putusan Pengadilan Agama Jakarta Pusat Nomor: 792/Pdt.G/2009/ PA.JP tanggal 10 Desember 2009, dan Menyatakan Pengadilan Agama Jakarta Pusat tidak berwenang memeriksa dan mengadili perkara a quo tersebut.

Terhadap Putusan Mahkamah Agung RI Nomor: 188 K/AG/2010 tersebut, Termohon Banding/Pemohon PK mengajukan Upaya Peninjauan Kembali. Alasannya adalah telah terjadi kekhilafan yang nyata pada salah satu amar Putusan tersebut yang menyatakan bahwa "Pengadilan Agama Jakarta Pusat tidak berwenang memeriksa dan mengadili perkara a quo". Hal tersebut tentunya telah mendorong Majelis Hakim untuk memberlakukan kembali putusan Basyarnas Nomor: 16/Tahun 2008/BASYARNAS/Ka.Jak, yang isinya melebihi dari hal yang tidak dituntut oleh Termohon Peninjauan Kembali I/Pemohon Arbitrase Syari'ah.

Alasan lainnya berdasarkan Pasal 49 Undang-Undang Nomor 3 Tahun 2006 Jo. Pasal 55 Undang-Undang Nomor 21 Tahun 2008 tentang Perbankan Syariah yang didasarkan pada alasan bahwa sengketa a quo berkaitan dengan sengketa Perbankan Syariah. Oleh karena itu Pengadilan Agama berwenang mengadili sengketa a quo "Bahwa namun di dalam amar putusan tersebut, judex factie justru menyatakan bahwa "Pengadilan Agama Jakarta Pusat tidak berwenang".

Berdasarkan alasan yang diajukan Pemohon PK tersebut, Mahkamah Agung berpendapat bahwa alasan-alasan peninjauan kembali yang diajukan oleh Pemohon Peninjauan Kembali tersebut tidak dapat dibenarkan. Mahkamah Agung dalam Pertimbangan Putusan PK nya menerangkan bahwa "Tidak terdapat adanya kekhilafan Hakim atau kekeliruan nyata" dalam putusan Mahkamah Agung Nomor: 188 K/AG/2010 tanggal 9 Juni 
2010 karena pertimbangannya telah tepat dan benar.

Para pihak yang bersengketa telah secara tegas telah menyatakan bahwa penyelesaian sengketa ini dilakukan dengan cara arbitrase sehingga berlakulah ketentuan Undang-Undang Nomor 30 Tahun 1999 tentang Arbitrase dan Alternatif Penyelesaian Sengketa sebagaimana diatur dalam Pasal 2 Undang-Undang tersebut, sehingga Pengadilan Negeri maupun Pengadilan Agama tidak berwenang untuk mengadili sengketa dimaksud (Pasal 3 Undang-Undang Nomor 30 Tahun 1999 tentang Arbitrase dan Alternatif Penyelesaian Sengketa).

Mengenai pembatalan putusan Arbitrase Nomor 16 Tahun 2008/ BASYARNAS/Ka.Jak tanggal 16 September 2009, maka sesuai ketentuan Pasal 71 UndangUndang Arbitrase dan Alternatif Penyelesaian Sengketa harus diajukan ke Pengadilan Negeri, bukan Pengadilan Agama. Adapun dasar hukum yang dipergunakan Pemohon PK yakni SEMA Nomor 8 Tahun 2008 ternyata bertentangan dengan Undang-Undang Nomor 48 Tahun 2009 tentang Kekuasaan Kehakiman Pasal 59 ayat (3) dan SEMA Nomor 8 Tahun 2008 tersebut telah dinyatakan tidak berlaku lagi oleh SEMA Nomor 8 Tahun 2010. Atas pertimbangan tersebut, Mahkamah Agung menyatakan permohonan peninjauan kembali dari Pemohon Peninjauan Kembali: PT. Bank Syari'ah Mandiri, Perseroan Terbatas (PT) tersebut "ditolak".

Selanjutnya dalam pertimbangan Majelis Hakim Mahkamah Agung juga disebutkan beberapa alasan ke-1 sampai dengan ke- 3 bahwa alasan-alasan peninjauan kembali yang diajukan oleh Pemohon Peninjauan Kembali tersebut tidak dapat dibenarkan, dengan pertimbangan sebagai berikut:

1. Tidak terdapat adanya kekhilafan Hakim atau kekeliruan nyata dalam putusan Mahkamah Agung Nomor: 188 K/AG/2010 tanggal 9 Juni 2010 karena pertimbangannya telah tepat dan benar;

2. Para pihak yang bersengketa telah secara tegas menyatakan bahwa penyelesaian sengketa ini dilakukan dengan cara arbitrase sehingga berlakulah ketentuan
Undang-Undang Nomor 30 Tahun 1999 tentang Arbitrase dan Alternatif Penyelesaian Sengketa sebagaimana diatur dalam Pasal 2 Undang-Undang tersebut, sehingga Pengadilan Negeri ataupun Pengadilan Agama tidak berwenang untuk mengadili sengketa dimaksud (Pasal 3 Undang-Undang Nomor 30 Tahun 1999 tentang Arbitrase dan Alternatif Penyelesaian Sengketa);

3. Dalam perkara a quo adalah tentang pembatalan putusan Arbitrase Nomor: 16 Tahun 2008/BASYARNAS/Ka.Jak tanggal 16 September 2009, maka sesuai ketentuan Pasal 71 Undang-Undang Arbitrase dan Alternatif Penyelesaian Sengketa harus diajukan ke Pengadilan Negeri (bukan Pengadilan Agama);

4. SEMA Nomor 8 Tahun 2008 ternyata bertentangan dengan Undang-Undang Nomor 48 Tahun 2009 tentang Kekuasaan Kehakiman Pasal 59 ayat (3) dan SEMA Nomor 8 Tahun 2008 tersebut telah dinyatakan tidak berlaku lagi oleh SEMA Nomor 8 Tahun 2010;

5. Berdasarkan Undang-Undang Nomor 30 Tahun 1999 pembatalan putusan Arbitrase harus berdasarkan alasan sebagaimana diatur dalam Pasal 70 dan dalam penjelasan pasal tersebut alasan pembatalan dimaksud harus dibuktikan dengan putusan pengadilan;

6. Karena yang dijadikan alasan pembatalan putusan Arbitrase tersebut adalah Pasal $70 \mathrm{C}$, yaitu adanya tipu muslihat, ternyata tidak ada bukti putusan pengadilan tentang adanya tipu muslihat dimaksud, sehingga karenanya putusan Pengadilan Agama tersebut telah dibatalkan oleh Mahkamah Agung dengan putusannya Nomor: 188 K/AG/2010 tersebut di atas;

Berdasarkan pertimbangan di atas, maka permohonan peninjauan kembali yang diajukan oleh Pemohon Peninjauan Kembali: PT. Bank Syari'ah Mandiri, Perseroan Terbatas (PT) tersebut harus ditolak. Demikian halnya, oleh karena permohonan peninjauan kembali dari Pemohon Peninjauan Kembali ditolak, maka Pemohon Peninjauan Kembali dihukum untuk membayar biaya perkara dalam pemeriksaan peninjauan kembali ini. 


\section{G. Penutup}

Arbitrase merupakan alternatif penyelesaian sengketa di luar pengadilan (non litigasi). Sengketa dan perselisihan kerap kali terjadi, terutama dalam dunia bisnis. Secara umum, masyarakat Indonesia menyelesaikan sengketa dengan cara musyawarah dan menjadikan para tetua adat sebagai penengah atas sengketa yang terjadi. Namun, seiring dengan semakin majunya peradaban, ada kecenderungan menggunakan lembaga pengadilan untuk menyelesaikan sengketa yang terjadi.

Meskipun demikian, lamanya proses pengadilan dan biaya yang relatif besar menjadi hambatan dalam menyelesaikan sengketa. Oleh karena itu, diperkenalkan alternatif. Untuk menyelesaikan sengketa di luar pengadilan, yakni melalui negosiasi, mediasi, konsiliasi dan arbitarse. Dalam konteks inilah, arbitrase menjadi alternatif penyelesaian suatu perselisihan (perkara) oleh seorang atau beberapa orang wasit (arbiter) yang bersama-sama ditunjuk oleh para pihak yang berperkara dengan tidak diselesaikan lewat Pengadilan, baik untuk perkara-perkara di tingkat nasional maupun internasional.

Mengacu kepada ketentuan Pasal 1 butir 1 Jo. Pasal 5 Undang-undang Nomor 30 Tahun 1999, sengketa yang dapat diselesaikan melalui arbitrase terbatas pada sengketa perdata, khususnya mengenai perdagangan dan mengenai hak yang menurut hukum dan peraturan perundang-undangan dikuasai sepenuhnya oleh pihak yang bersengketa. $\mathrm{Na}$ mun demikian tidak semua perkara bisa diselesaikan melalui arbitrase. Tetapi untuk jenis perkara berupa sengketa perdata tentu dapat diselesaikan dengan cara arbitrase, dengan keunggulan dilakukan secara sederhana, cepat, dan biaya ringan.

\section{Daftar Pustaka}

Harahap, M. Yahya. 1991. Arbitrase Ditinjau dari: Reglemen Acara Perdata (Rv), Prosedur BANI, International Centre for the Settlement of Investment Dispute (ICSID), UNICITRAL Arbitration Rules, Convention on the Recognition and Enforce- ment of Foreing Arbitral Award, PERMA No. 1 Tahun 1990. Jakarta: Pustaka Kartini.

M. Nolan-Haley, Jacqueline. 1992. Alternative Dispute Resolution in a Nutshell. St. Paul: West Publishing Co.

Siburian, Paustinus. 2006. Arbitrase Online (Alternatif Penyelesaian Sengketa Perdagangan Secara Elektronik). Jakarta: Djambatan.

Soemartono, Gatot. 2006. Arbitrase dan Mediasi di Indonesia. Jakarta: PT Gramedia Pustaka Utama.

Subekti, R. 1979. Arbitrase Perdagangan. Bandung: Bina Cipta.

Budhy Budiman. Mencari Model Ideal Penyelesaian Sengketa: Kajian Terhadap Praktik Peradilan Perdata dan Undang-Undang Nomor 30 Tahun 1999, artikel dalam http://www.uika-bogor.ac.id/juro5.htm, diakses 10 September 2013.

H.M.N. Purwosutjipto, Arbitrase dan Penyelesaian Sengketa Perdata, dalam http://dodiksetiawan.wordpress.com/2009/04/ 14/definisi-arbitrase, diakses tanggal 10 September 2013.

Iqbal Amaludin, Penyelesaian Sengketa Hukum Melalui Arbitrase, dalam http://iqbalamaludin.blogspot.com/2013/04/vbehaviorurldefaultvmlo.html diakses tanggal 10 Oktober 2013.

Liliana Tedjosaputro, menjelaskan pengertian penegakan hukum sebagaimana dikutip dari http://hukum-on.blogspot.com/2012/06/pengertian-supremasihukum-dan.html, diakses 10 Oktober 2013, diakses 6 November 2012.

Mirza Riviera, Penegakan Hukum di Indonesia, artikel dalam http://viarviorviera. Blogspot.com/2012/03/penegakan-hukum-diindonesia.html, diakses tanggal 10 Oktober 2013.

Pan Mohammad Faiz, Klausul Arbitrase dan Pengadilan dalam Penyelesaian Sengketa, artikel dalam http://jurnalhukum.blogspot.com/2006/09/klausul-arbitrase-danpengadilan_18.html, diakses tanggal 10 September 2013.

Priyatna Abdurrasyid, Arbitrase: Solusi Alternatif Penyelesaian Sengketa Perdata, dalam http://id.shvoong.com/law- 
112 | Asy-Syari'ah Vol. 16, No. 2, Agustus 2014

and-politics/1908998-keunggulan-dankelemahan-arbitrase. Diakses tanggal 10 Septmeber 2013.

Purnadi Purbacaraka menjelaskan pengertian penegakan hukum sebagaimana dikutip dari http://hukum-on.blogspot. com/2012/06/pengertian-supremasihukum-dan.html, diakses 10 Oktober 2012.
Sasmitasari, Pengertian Penegakan Hukum, artikel dalam http://sasmitasmansa. Wordpress.com/2011/12/07/pengertianpenegakan-hukum, diakses tanggal 10 Oktober 2012. 